\title{
MORPHOTECTONICS OF THE PSATHOPYRGOS ACTIVE FAULT, WESTERN CORINTH RIFT, CENTRAL GREECE
}

\author{
Tsimi Ch. ${ }^{1}$, Ganas A. ${ }^{1}$, Soulakellis N. ${ }^{2}$, Kairis O. ${ }^{3}$, and Valmis S. ${ }^{3}$ \\ ${ }^{1}$ Institute of Geodynamics, National Observatory of Athens, 11810 Athens, Greece \\ aganas@gein.noa.gr \\ ${ }^{2}$ Department of Geography, University of the Aegean, University Hill, 81100 Mytilene, Greece \\ ${ }^{3}$ Agricultural University of Athens, Iera Odos 75, 11855 Athens, Greece
}

\begin{abstract}
The study area is located on the western part of the Gulf of Corinth which is considered as a paradigm of an active rift system in Greece. This rift was formed by normal slip on big faults which extend the crust of the Earth in the N-S direction. The morphotectonic indices (hypsometric curve, hypsometric integral, drainage basin asymmetry, ratio of valley floor width to valley height) have been estimated using the 20-m digital elevation model of this area and the ARC software. The normal faults of the study area have been extracted by use of a DEM mosaic of 20$m$ pixel size, satellite images from Landsat 7 ETM+ and SRTM $90 \mathrm{~m}$. Our results highlight the recent activity of the Psathopyrgos normal fault on the basis of a series of morphotectonic evidence and suggest the existence of a single fault segment for a distance of $16 \mathrm{~km}$.
\end{abstract}

Key words: Morphotectonics, Corinth rift, Psathopyrgos, active faults.

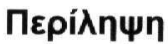

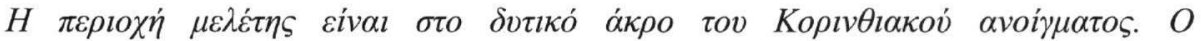

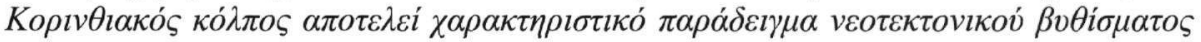

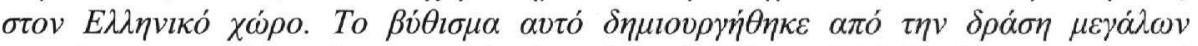

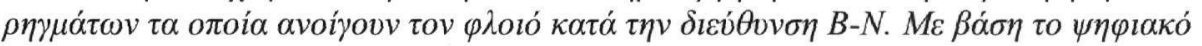

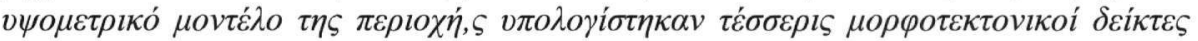

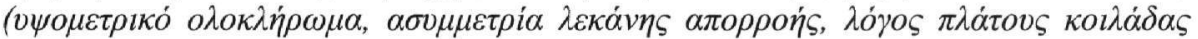

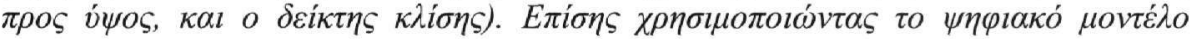

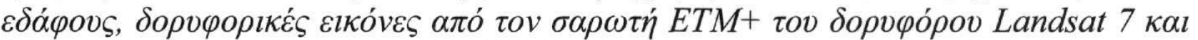

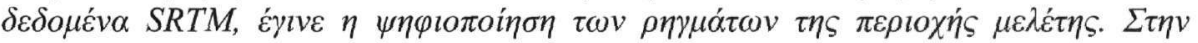

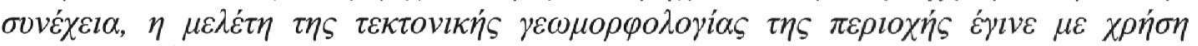

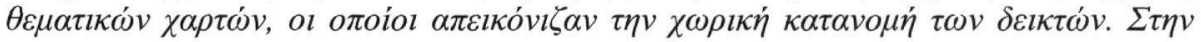

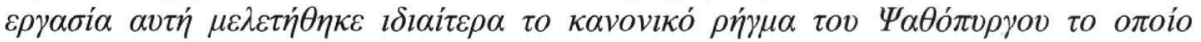

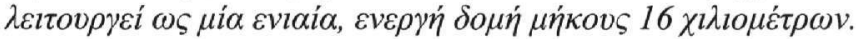

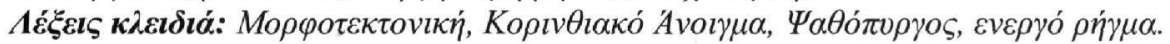




\section{Introduction}

The main aim of this work is the understanding of long-term tectonic processes in the Psathopyrgos area of the western Corinth Rift area through the construction of a series of digital maps showing the spatial distribution of the main morphotectonic indices. The morphotectonic analysis helps to identify tectonic processes at the surface (Keller and Pinter, 1996). Our objectives are a) the mapping of the spatial distribution of the morphotectonic indices over a total area of 19.74 square kilometres $\left(\mathrm{km}^{2}\right.$, Fig. 1), b) the spatial relationship between the slip rate of the Psathopyrgos active fault and particular indices and c) the creation of a digital database of the geomorphology characteristics in the study region. In this paper we will present a fraction of our results around the Psathopyrgos area that have been validated in the field.

In central Greece, large, shallow earthquakes $(M>6)$ are found to rupture pre-existing fault scarps such as the 1981 earthquakes in the eastern end of the gulf of Corinth (Jackson et al. 1982). Every large earthquake creates a permanent deformation at the Earth's surface (Stein et al. 1988), resulting in the uplift of the footwall area and the subsidence of the hangingwall area, respectively. The key factor in shaping the landscape in such areas is the relation of the fault slip rate to the erosion rate, in other words in areas deformed by fast-moving faults the geomorphological signal will be much different from areas with slow-moving faults.

The spatial criteria for the recognition of active normal faults are (Jackson and Leeder 1994, Ganas 1997) a) the alignment of fault scarps along the base of mountain fronts b) the elliptical shape of the footwall area as observed in along-fault strike profiles c) the development of axial drainage in the hangingwall area and d) the development of trellis-type drainage in the footwall area with discharge of footwall catchments at both ends of segments. In this work we used a combination of techniques including use of orthorectified Landsat 7 image, a 20-m DEM mosaic and its byproducts (slope map, contours, TIN, shaded relief), a 90-m SRTM elevation model, geological data published in the literature and our own field work.

\section{The study region}

The study area is the western part of the Gulf of Corinth which is considered to be a paradigm of an active rift system in Greece (Fig. 1; De Martini et al. 2004, Pavlides et al. 2004, Pantosti et al. 2004, Bernard et al. 2006). This rift was formed by normal slip on large, E-W striking faults which extend the crust of central Greece in the N-S direction. The length of Corinth rift is $130 \mathrm{~km}$ and the width is $20-40 \mathrm{~km}$. The major depth is $\sim 900 \mathrm{~m}$ and the major height of the mountains around the Gulf of Corinth is $\sim 2500 \mathrm{~m}$. The south coast of the Corinth rift is uplifting whereas the north part is subsiding. From space geodesy we know that the Peloponnesus (southern part) moves faster towards southwest than the Greek mainland (Clarke et al. 1998). The result from this movement is that these two areas move away from each other with an average speed of $1 \mathrm{~cm} /$ year and increasing from east to west. The bedrock lithology is mainly limestone and the syn-rift rocks are Pliocene - Quaternary age sedimentary rocks such as marls, sandstones, conglomerates and alluvial fan deposits.

In the study region, the active faults have normal kinematics. The area includes some of the most active faults in Greece that have already been studied by many researchers. For example, the Eliki Fault, which is approximately $40 \mathrm{~km}$ long ruptured during two important catastrophic earthquakes in $373 \mathrm{BC}$ and in 1861 (Schmidt 1879). Moreover the study area has rugged relief, several major rivers flowing in the general N-S direction (Fig. 1), many narrow valleys and a lot of other interesting landforms. Within our study area the drainage is organized in fifty six (56) catchments. The catchments developed in the footwall area of the Psathopyrgos normal fault amount to fourteen (14). The morphotectonic data for all catchments are presented in Table 1. 


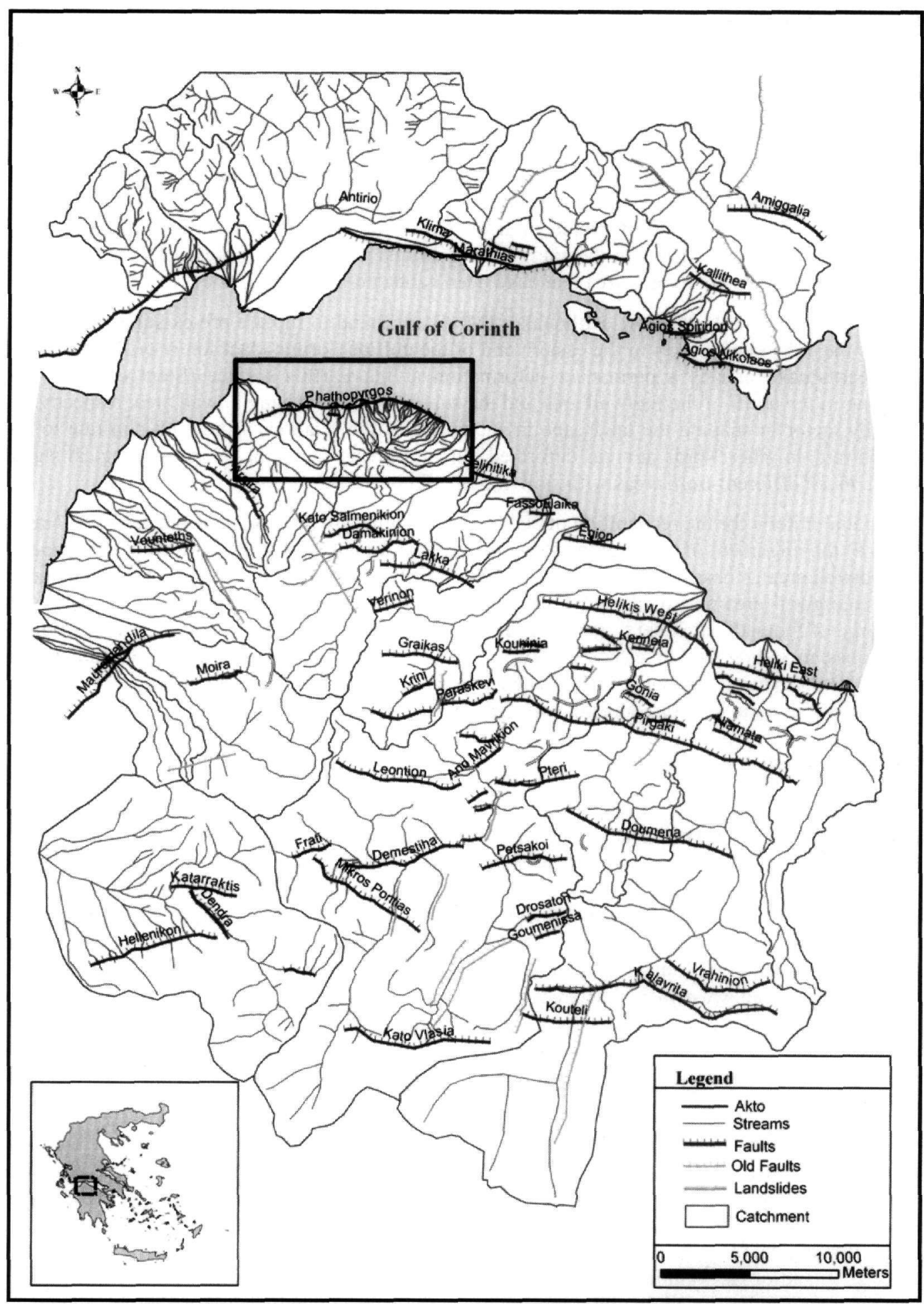

Figure 1 - Map of the study area in Western Peloponnesus and Sterea Hellas. Numbers indicate main catchments. Note the E-W orientation of active faults and the N-S orientation of major rivers. Names of faults are after published literature or by the nearest village/town. Square box indicates the Psathopyrgos fault area 


\section{Materials and Methods}

The software that was used was $A r c G I S^{T M}$ v.8.1 for Windows. From the available to us digital data, we digitized a) the catchments $(56), b)$ the streams c) the landslides, d) the triangular facets developed on the footwall area of the large, normal faults and e) the normal faults as mapped by Doutsos and Poulimenos (1992), Roberts and Koukouvelas (1996) and by our own field work. The faults were located precisely by collecting fault plane coordinates using field GPS. The feature "active fault" includes 5 fields (attributes) namely the name of the fault, the length, the strike, the distance to the watershed (D to Divide) and the relief of each of them $\mathrm{H}_{\max }-\mathrm{H}_{\min }$ (where $\mathrm{H}_{\max }$ is the maximum elevation in the footwall of the fault and Hmin is the minimum elevation in the hangingwall).

The estimated morphometric indices of this study are the following:

- Hypsometric curve and hypsometric integral (HI)

$$
H I=\frac{H_{\text {mean }}-H_{\min }}{H_{\max }-H_{\min }}
$$

where $H_{\text {mean }}, H_{\max }$ and $H_{\min }$ are the mean, maximum and minimum elevation, respectively.

- $\quad$ Drainage basin asymmetry $(A F)$

$$
A F=100 *(A r / A t)
$$

where $A r$ is the size of area in the right sub-catchment of main river and $A t$ is the area of whole catchment.

- Ratio of valley floor width to valley height $(V)$

$$
V=\frac{2 V_{f w}}{\left(h_{1}-h_{3}\right)+\left(h_{2}-h_{3}\right)}
$$

where $V_{f}$ is the width of the valley floor, $h_{1}$ and $h_{2}$ are the elevation of the right and left drainage basic line and $h_{3}$ is the elevation of the valley floor.

In this paper we will present the results concerning the spatial distribution of the hypsometric integral (relation 1), the basin asymmetry index (relation 2), and the variation of the slope of the triangular facets along the fault. We also discuss the implications of the above morphotectonic indices and in particular the Valley Height-width ratios (relation 3) for the Psathopyrgos fault.

\section{Results and Discussion}

Our results are presented in tabular form below (Tables 1,2) and as maps (Fig. 2 and so on). Table 1 summarises the selected morphotectonic indices for all catchments in Figure 1. Figure 2 presents the spatial distribution of hypsometric integrals and Figure 3 the basin asymmetry, respectively. The map of the hypsometric integral (relation 1) shows very high values in the catchments where their main rivers pour out in the Psathopyrgos and Marathias hangingwall regions (Fig. 2, catchments 13 to 29 and 46 to 50). The Psathopyrgos normal fault strikes E-W and its footwall catchments show values ranging from $\mathrm{HI}=0.5$ to 0.7 . The Marathias normal fault also strikes $\mathrm{E}-\mathrm{W}$ and its footwall catchments range from $\mathrm{HI}=0.35-0.60$. This means that these regions have a high mean topography which results from high rates of tectonic activity as demonstrated by the rapid uplift of the footwall of Psathopyrgos fault $(0.7-0.8 \mathrm{~mm} / \mathrm{year}$; Houghton et al. 2003). Also, the hypsometric integral has a relatively high value in the catchments 1 to 5 , which have been developed in the footwall area of the Eliki fault. The uplift rate of the footwall area has been determined by De Martini et al. (2004) as 1.0- $1.25 \mathrm{~mm} /$ year for the East and West Eliki Fault respectively. There is no geological data for uplift rates along the Marathias normal fault. 
Table 1- Selected morphotectonic indices of the catchments of the area shown in Figure 1. Shaded rows indicate the catchments of the Psathopyrgos fault

\begin{tabular}{|c|c|c|c|c|c|}
\hline Catchments & Area $\left(m^{2}\right)$ & $\overline{\text { Af }}$ & $\mathrm{Vr}$ & Hypsometric Integral & Mean Slope \\
\hline 1 & 47811930 & 56.3 & 0.56 & 0.48 & 19.39 \\
\hline 2 & 241417496 & 43.3 & 0.29 & 0.44 & 19.55 \\
\hline 3 & 84056971 & 44.7 & 0.55 & 0.49 & 20.96 \\
\hline 4 & 5094981 & 35.3 & 0.52 & 0.39 & 16.84 \\
\hline 5 & 364478057 & 53.0 & 0.34 & 0.44 & 18.27 \\
\hline 6 & 64762857 & 32.2 & 3.73 & 0.43 & 15.45 \\
\hline 7 & 6815984 & 48.5 & 1.23 & 0.31 & 11.69 \\
\hline 8 & 15683779 & 27.6 & 1.38 & 0.28 & 13.90 \\
\hline 9 & 2348542 & 53.7 & 2.80 & 0.46 & 16.59 \\
\hline 10 & 87350558 & 31.3 & 4.43 & 0.40 & 17.59 \\
\hline 11 & 3121492 & 44.6 & 1.21 & 0.32 & 10.84 \\
\hline 12 & 1791911 & 35.3 & 1.68 & 0.32 & 11.05 \\
\hline 13 & 1804260 & 48.1 & 1.11 & 0.49 & 17.91 \\
\hline 14 & 1359765 & 48.9 & 0.43 & 0.55 & 17.16 \\
\hline 15 & 699527 & 38.8 & 1.15 & 0.50 & 18.75 \\
\hline 16 & 1104390 & 42.6 & 1.02 & 0.65 & 20.17 \\
\hline 17 & 222091 & 50.7 & 1.80 & 0.56 & 22.27 \\
\hline 18 & 263749 & 45.7 & 1.65 & 0.56 & 21.86 \\
\hline 19 & 782921 & 49.2 & 1.31 & 0.55 & 21.20 \\
\hline 20 & 216557 & 34.0 & 6.55 & 0.59 & 20.64 \\
\hline 21 & 378501 & 44.7 & 1.70 & 0.65 & 19.85 \\
\hline 22 & 1496489 & 42.5 & 1.23 & 0.61 & 20.97 \\
\hline 23 & 1632240 & 58.2 & 0.41 & 0.54 & 26.30 \\
\hline 24 & 3524198 & 56.7 & 1.04 & 0.61 & 17.46 \\
\hline 25 & 1471935 & 42.4 & 1.23 & 0.65 & 16.28 \\
\hline 26 & 2623371 & 60.8 & 0.66 & 0.54 & 19.40 \\
\hline 27 & 3970058 & 53.6 & 0.56 & 0.62 & 17.79 \\
\hline 28 & 28548291 & 28.3 & 0.47 & 0.35 & 16.61 \\
\hline 29 & 1033524 & 23.9 & 1.04 & 0.55 & 18.62 \\
\hline 30 & 2074864 & 48.2 & 15.8 & 0.48 & 16.25 \\
\hline 31 & 10365813 & 53.1 & 1.58 & 0.42 & 17.17 \\
\hline 32 & 18112766 & 58.6 & 0.64 & 0.27 & 13.94 \\
\hline 33 & 21327503 & 55.9 & 3.22 & 0.49 & 18.07 \\
\hline 34 & 3613023 & 50.1 & - & 0.30 & 8.74 \\
\hline 35 & 13484145 & 41.8 & 1.23 & 0.32 & 12.18 \\
\hline 36 & 25993049 & 72.5 & 1.23 & 0.27 & 12.89 \\
\hline 37 & 78844225 & 67.9 & 0.61 & 0.47 & 16.56 \\
\hline 38 & 11397941 & 54.7 & 1.95 & 0.26 & 14.12 \\
\hline 39 & 12495250 & 45.5 & 0.82 & 0.57 & 17.23 \\
\hline 40 & 174732155 & - & - & 0.29 & 14.70 \\
\hline 41 & 34297310 & 40.4 & 0.90 & 0.27 & 15.67 \\
\hline 42 & 876311 & 46.8 & 1.38 & 0.36 & 17.16 \\
\hline 43 & 1392420 & 38.3 & 1.79 & 0.32 & 19.13 \\
\hline 44 & 32693871 & 48.9 & 3.97 & 0.45 & 22.36 \\
\hline
\end{tabular}




\begin{tabular}{|c|c|c|c|c|c|}
\hline 45 & 2901191 & 47.8 & 2.22 & 0.20 & 6.37 \\
\hline 46 & 143503704 & - & - & 0.39 & 19.09 \\
\hline 47 & 31518661 & 42.1 & 0.12 & 0.50 & 22.17 \\
\hline 48 & 19166567 & 67.2 & 0.73 & 0.55 & 25.07 \\
\hline 49 & 4367131 & 42.5 & 0.67 & 0.47 & 21.21 \\
\hline 50 & 13226043 & 48.1 & 0.21 & 0.40 & 18.41 \\
\hline 51 & 9986878 & 54.6 & 1.39 & 0.40 & 21.64 \\
\hline 52 & 2878776 & 35.7 & 1.26 & 0.51 & 22.90 \\
\hline 53 & 1379537 & 39.2 & 0.96 & 0.49 & 24.33 \\
\hline 54 & 4694924 & 45.5 & 0.97 & 0.46 & 18.80 \\
\hline 55 & 3191160 & 41.7 & 2.23 & 0.53 & 20.10 \\
\hline 56 & 71315140 & 58.5 & 3.29 & 0.45 & 19.67 \\
\hline
\end{tabular}

The map of the Basin Asymmetry factor (AF; relation 2) shows the catchments along the Psathopyrgos fault follow the long-term slip rate distribution, i.e. catchments 14 to 22 show values less than $50 \%$ indicating tilt to the right (east). Catchments 17 and 19 show AF values near 50 indicating the transitional "signal" between the two tilt directions along strike. On the other hand, catchments 23 to 27 show values greater than 50 indicating tilt to the left (west). This result allows us to suggest that Psathopyrgos is a mechanically isolated normal fault, so its footwall profile follows an elliptical shape, therefore tilt direction switches from east to west along strike. Along the Marathias fault the tilt is generally to the west with the exception of catchment 48 (Sergoula stream) which is tilted to the east. Along the Eliki Fault the distal catchments (1 and 5) show values greater than 50 (tilt to the right - east) while the proximal catchments $(2,3$ and 4$)$ are tilted to the left (west). As the hinterland of the Eliki fault is also deformed by other, parallel normal faults it is difficult to interpret this tilt pattern. The step over area between the two Eliki segments (Fig. 1) belongs to the catchment of river Kerinitis and shows a moderate tilt to the west (45).

The mean slope map of catchments shows that catchments in the footwall area of Psathopyrgos and Marathias faults have the highest values. Catchment slopes along Psathopyrgos range from $16.2^{\circ}-26.3^{\circ}$ and those along Marathias from $18.4^{\circ}-25^{\circ}$, respectively. The catchment of Kerinitis river shows the highest mean slope $\left(20.9^{\circ}\right)$ in the footwall area of the Eliki fault.

The Psathopyrgos normal fault at the westernmost end of the Gulf of Corinth (Fig. 1) has been studied in more detail as it shows the characteristic elliptical profile of footwall elevations (Fig. 5). The footwall catchments have been analysed and four morphotectonic indices have been calculated, namely the Hypsometric integral, the mean slope, the valley width-to-height ratio and the basin asymmetry factor. All values are given in Table 3 below.

The footwall area of the Psathopyrgos normal fault is dissected by a dozen of streams with N-S flow. Stream downcutting has developed a series of characteristic erosional landforms along the mountain front, the triangular facets (Fig. 3). Facet slope varies along strike from $15.3^{\circ}$ (east end) to $25.8^{\circ}$ (west end) with highest values towards the west (slope $>30^{\circ}$; Fig. 4). This data support a weak correlation between mountain front lithology and mean slope of facets. Also, the high mean slope values are characteristic of active faulting (e.g. Ganas et al. 2005). A second important observation concerns the east-west distribution of the asymmetry factor (Fig. 6). The catchment asymmetry shows a flip in the tilt direction at about $5 \mathrm{~km}$ along strike (from eastward to westward) which is in agreement with the elevation change seen on the footwall profile (Fig. 5). A third observation concerns the distribution of the valley width-to-height ratio. We calculate this ratio upstream of the mountain front for all fourteen catchments along the Psathopyrgos fault (Table 3 ). The ratio plot (Fig. 6) shows values $>1$ at distances 2000-7000 $\mathrm{m}$ along strike which is in disagreement with values $<1$ at both fault ends and towards the middle. This discrepancy is not due to a lack of tectonic uplift and the development of U-shaped valleys in this area but to the 


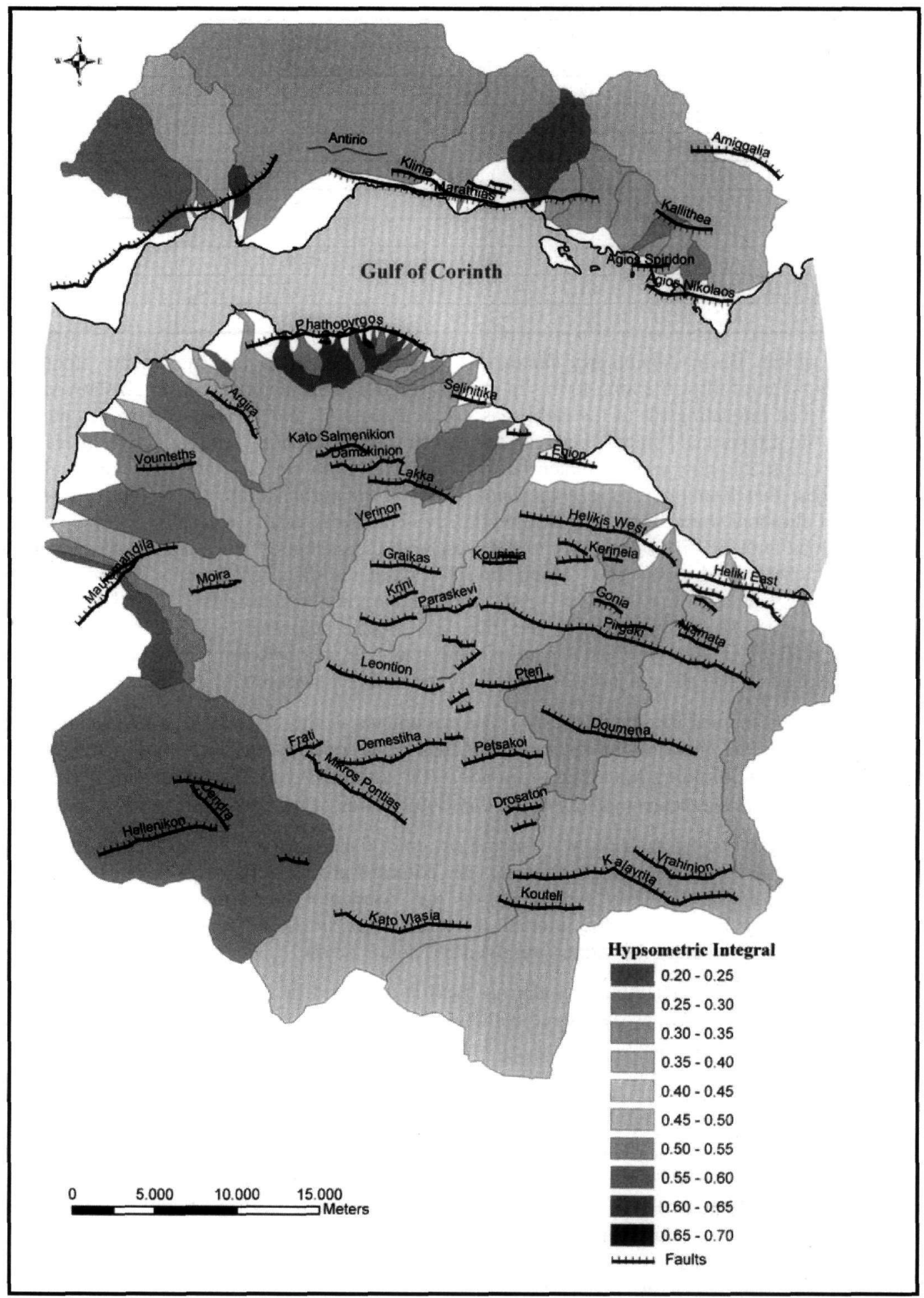

Figure 2 - Map showing the spatial distribution of the hypsometric integral for every catchment. The dark color indicates a high mean topography, while the light color indicates a low topography 


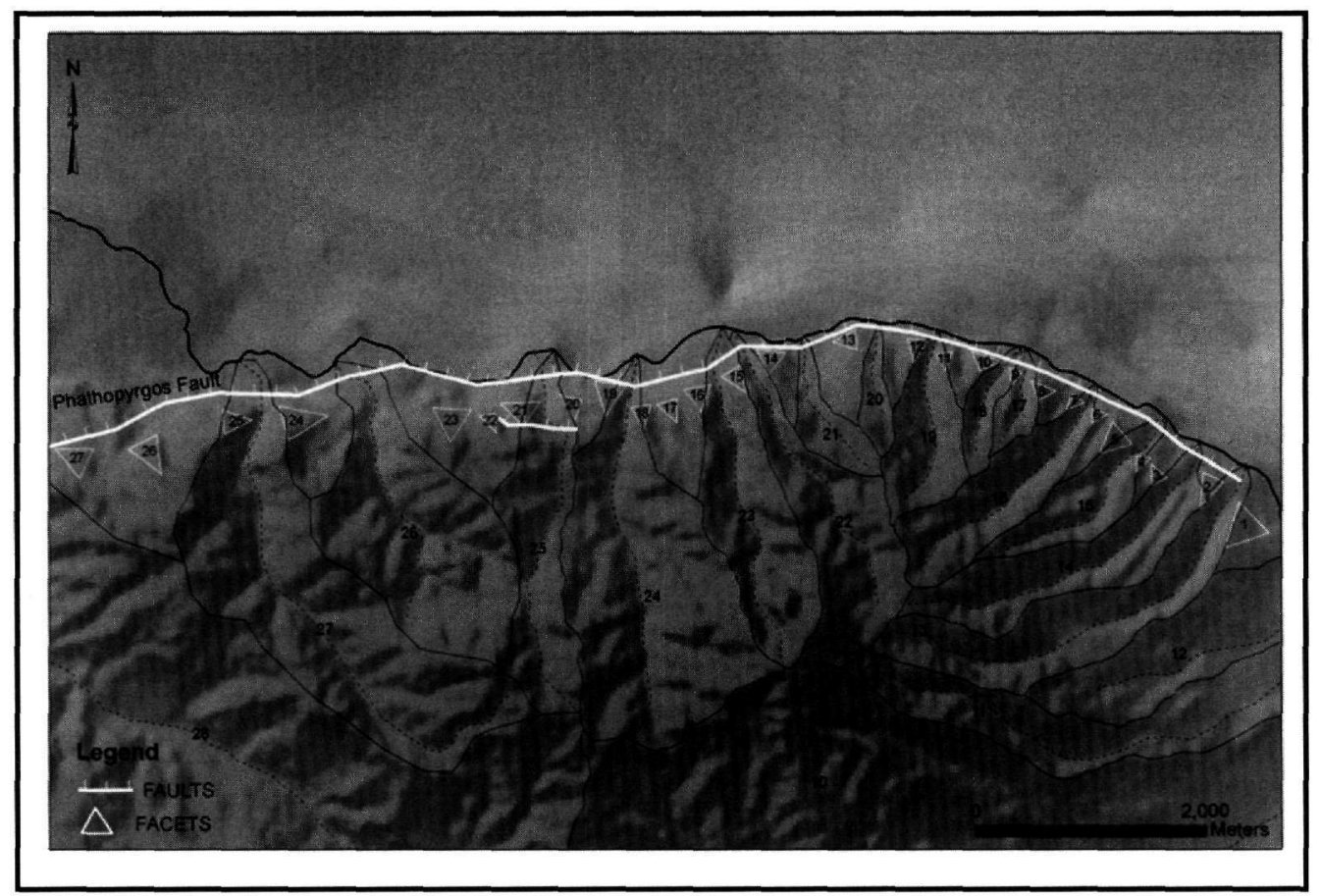

Figure 3 - Map of the Psathopyrgos fault area showing the catchments and triangular facets on its footwall. Integers inside triangles indicate facet numbering along strike

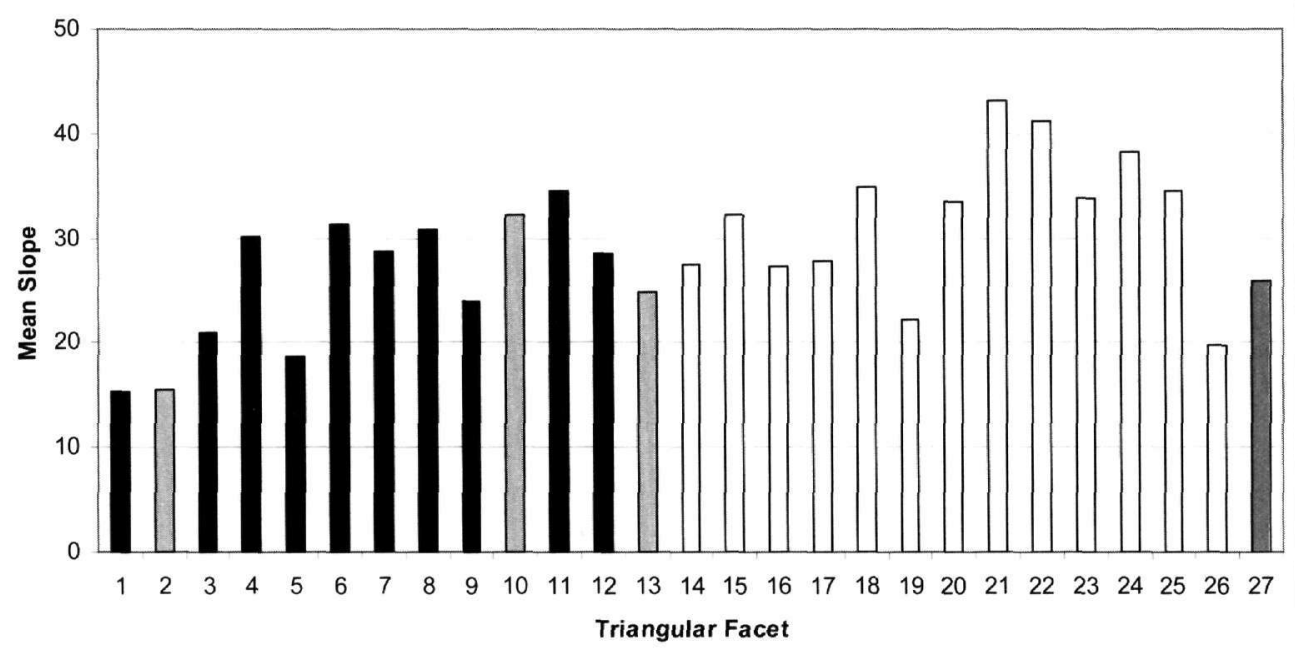

Figure 4 - Bar graph showing the mean slope of the triangular facets along the Psathopyrgos normal fault. Facet colour is according to lithology (Table 2). Facet number is shown in Figure 3 
Table 2 - Size (area) and mean slope for each of the triangular facets in the footwall area of the Psathopyrgos Fault. Facet numbering is shown in Figure 3

\begin{tabular}{|c|c|c|c|}
\hline Number of the Triangular Facets & Area $\left(\mathrm{m}^{2}\right)$ & Mean slope $\left({ }^{\circ}\right)$ & Lithology \\
\hline 1 & 67500 & 15.34 & Syn-rift (conglomerate) \\
\hline 2 & 28800 & 15.45 & Syn-rift (scree) \\
\hline 3 & 12600 & 20.88 & Syn-rift (conglomerate) \\
\hline 4 & 8100 & 30.16 & Syn-rift (conglomerate) \\
\hline 5 & 36000 & 18.71 & Syn-rift (conglomerate) \\
\hline 6 & 8100 & 31.40 & Syn-rift (conglomerate) \\
\hline 7 & 9000 & 28.68 & Syn-rift (conglomerate) \\
\hline 8 & 16200 & 30.85 & Syn-rift (conglomerate) \\
\hline 9 & 8100 & 24.03 & Syn-rift (conglomerate) \\
\hline 10 & 18000 & 32.14 & Syn-rift (scree) \\
\hline 11 & 11700 & 34.48 & Syn-rift (conglomerate) \\
\hline 12 & 19800 & 28.44 & Syn-rift (conglomerate) \\
\hline 13 & 16200 & 24.85 & Syn-rift (scree) \\
\hline 14 & 28800 & 27.44 & Pre-rift (limestone) \\
\hline 15 & 50400 & 32.22 & Pre-rift (limestone) \\
\hline 16 & 18000 & 27.28 & Pre-rift (limestone) \\
\hline 17 & 16200 & 27.89 & Pre-rift (limestone) \\
\hline 18 & 38700 & 34.84 & Pre-rift (limestone) \\
\hline 19 & 17100 & 22.17 & Pre-rift (limestone) \\
\hline 20 & 37800 & 33.53 & Pre-rift (limestone) \\
\hline 21 & 13500 & 43.16 & Pre-rift (limestone) \\
\hline 22 & 47700 & 41.18 & Pre-rift (limestone) \\
\hline 23 & 60300 & 33.77 & Pre-rift (limestone) \\
\hline 24 & 27900 & 38.18 & Pre-rift (limestone) \\
\hline 25 & 43200 & 34.44 & Pre-rift (limestone) \\
\hline 26 & 37800 & 19.76 & Pre-rift (limestone) \\
\hline 27 & 48600 & 25.87 & $\begin{array}{l}\text { Syn-rift (marly lim.- } \\
\text { scree) }\end{array}$ \\
\hline
\end{tabular}

influence of the relatively weak lithology (syn-rift conglomerates). This lithology is more susceptible to hillslope erosion, upstream of the mountain front. Low $\mathrm{Vr}$ values $(<1)$ indicate strong incision by streams due to tectonic uplift. For example such values are observed along the Eliki Fault (Verrios et al. 2004) where the 1861 earthquake ruptures were observed (Schmidt 1879).

We analysed the elevation profile of the footwall in order to examine if it can be fit by an elliptical line in accordance with other profiles along isolated, normal fault segments in central Greece (Ganas et al. 2005). Figure 5 shows the graph showing the footwall elevations along the Psathopyrgos active fault. We observe that the overall elliptical shape is maintained with high confidence as $\mathrm{R}^{2}$ values range between 0.84 (quadratic fit) and 0.90 (cubic fit).

\section{Conclusions}

a) We studied the morphotectonics of the western Gulf of Corinth and focused our attention to the Psathopyrgos normal fault. This fault strikes E-W and its footwall catchments show values ranging from $\mathrm{HI}=0.5$ to 0.7 . This means that this region has a high mean topography which results from high rates of tectonic activity. 


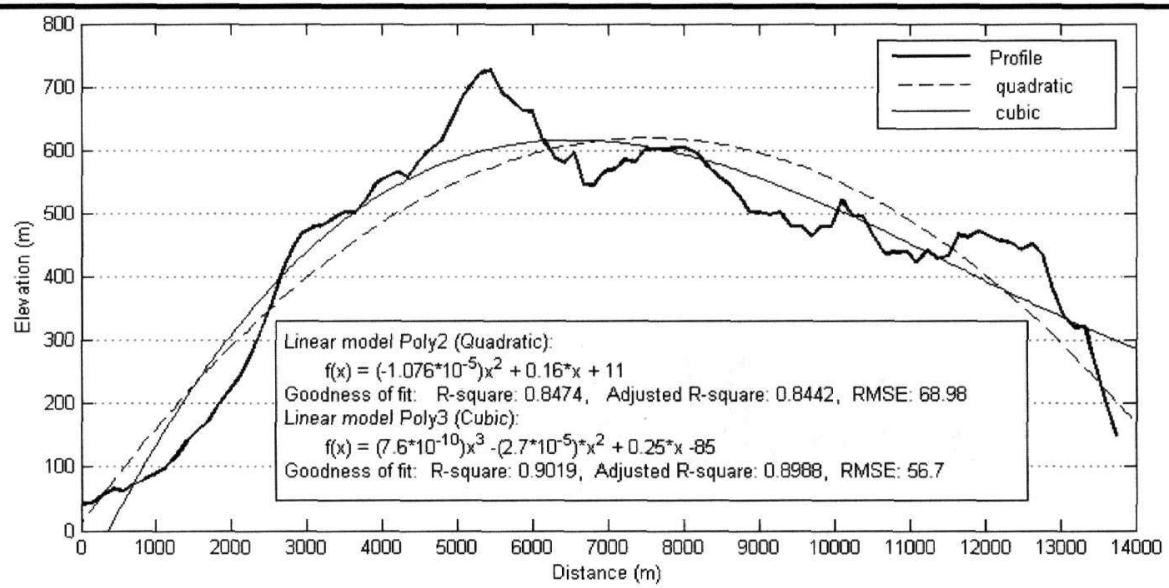

Quadratic: norm of residuals $=675.9021$

Cubic: norm of residuals $=555.5564$

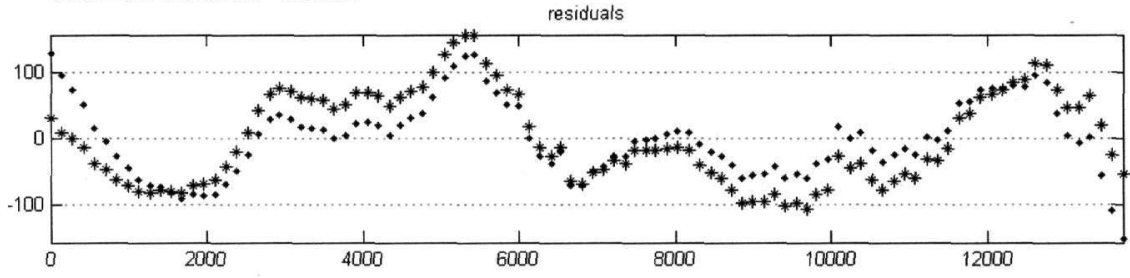

Figure 5 - (Top) Graph showing the footwall elevations along the Psathopyrgos active fault. Also drawn are best-fit curves for quadratic (dashed line) and cubic polynomials (solid line).

Vertical exaggeration times 10. (Bottom) Graphs showing goodness of fit along footwall distance. In most cases the cubic fit (dots) is better

Table 3 - Morphotectonic indices along the Psathopyrgos normal fault. The ratio Vr is measured upstream from the mountain front and its distance is given in $\mathbf{m}$

\begin{tabular}{|c|c|c|c|c|}
\hline Distance (m) & H. Integral & Mean Slope/rad & Valley (Vr)-Distance to Fault & As/100 \\
\hline 468.30 & 0.55 & 0.30 & $0.43-1284$ & 0.49 \\
\hline 863.29 & 0.50 & 0.33 & $0.98-477$ & 0.39 \\
\hline 1531.38 & 0.65 & 0.35 & $0.94-723$ & 0.43 \\
\hline 2148.50 & 0.56 & 0.39 & $1.44-282$ & 0.51 \\
\hline 2305.50 & 0.56 & 0.38 & $1.20-404$ & 0.46 \\
\hline 2971.90 & 0.55 & 0.37 & $1.30-241$ & 0.49 \\
\hline 3474.08 & 0.59 & 0.36 & $1.50-464$ & 0.34 \\
\hline 4172.08 & 0.65 & 0.35 & $1.40-642$ & 0.45 \\
\hline 4729.70 & 0.61 & 0.37 & $1.07-763$ & 0.43 \\
\hline 5018.40 & 0.54 & 0.46 & $0.41-623$ & 0.58 \\
\hline 5775.60 & 0.61 & 0.30 & $0.97-267$ & 0.57 \\
\hline 7318.78 & 0.65 & 0.28 & $1.18-268$ & 0.42 \\
\hline 10611.98 & 0.54 & 0.34 & $0.66-689$ & 0.61 \\
\hline 14684.12 & 0.62 & 0.31 & $0.56-513$ & 0.54 \\
\hline
\end{tabular}




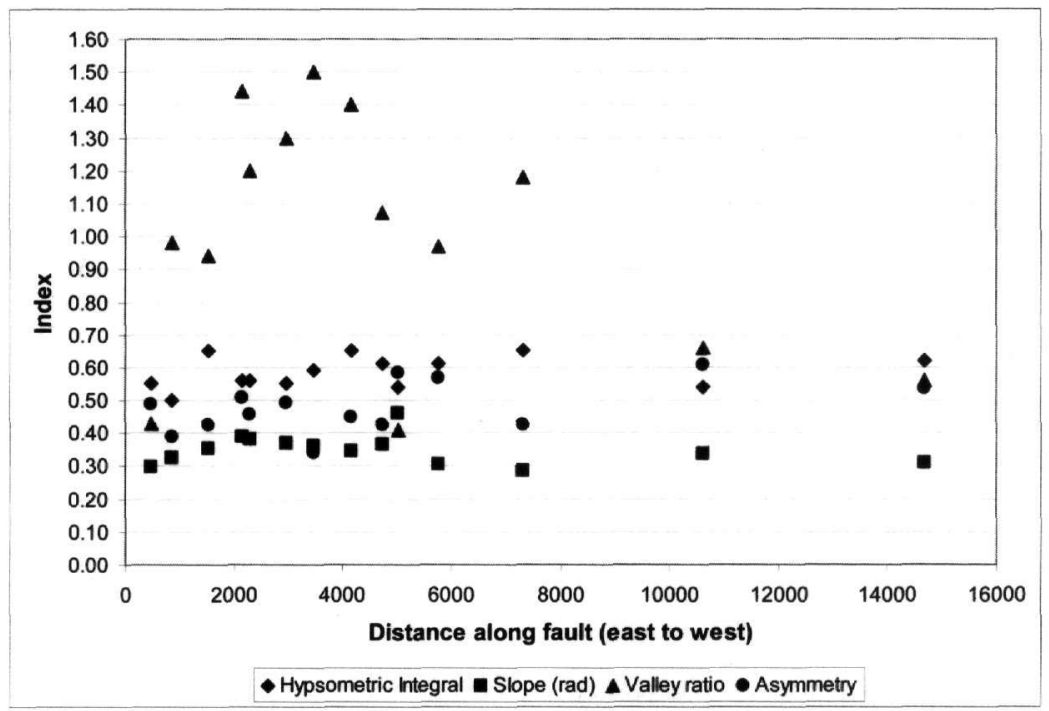

Figure 6 - Graph showing the distribution of morphotectonic indices along the Psathopyrgos Fault. Values of indices are presented in Table 2. In order to maintain a similar Y-axis in this plot the mean slope of catchments is given in radians and the basin asymmetry index is divided by 100

b) The Psathopyrgos fault is a mechanically isolated normal fault, because its footwall elevation profile follows an elliptical shape (Fig. 5) and its footwall tilt direction switches from east to west along strike. The footwall best-fit curve is a cubic polynomial.

c) Mean values of triangular facets are high indicating active faulting. A weak correlation is observed between the mean slope of facets and the lithology of the footwall. Facets developed on limestone have high values $\left(>30^{\circ}\right)$.

d) The variation of Vr ratio along the Psathopyrgos fault shows values $>1$ at distances $2-7$ $\mathrm{km}$ away for the east end. This is not the result of lack of tectonic uplift but it is due to the existence of relatively weak lithology of the syn-rift (conglomerates). Vr values $<1$ exhibit valleys developed on bedrock (limestone). In fact, the lowest values of $\mathrm{Vr}$ exist at both ends of the fault where long-term slip rates are expected to be the lowest. This observation may suggest that these areas have experienced very recent uplift and intense down-cutting as a result of bi-directional fault growth.

\section{Acknowledgments}

We thank Professor Pavlides for reviewing the paper and Prof. Hara Drinia for editorial assistance. Sotiris Sboras helped with ARC processing. The $90-\mathrm{m}$ SRTM data set was provided by NASA free of charge. The $20-\mathrm{m}$ DEM mosaic was provided by GEOINFO ltd.

\section{References}

Bernard, P., Lyon-Caen, H., Briole, P., et al., 2006. Seismicity, deformation and seismic hazard in the western rift of Corinth: New insights from the Corinth Rift Laboratory (CRL), Tectonophysics, 426 (1-2), 7-30.

Clarke, P.J., Davies, R.R., England, P.C,. Parsons, B., Billiris, H., Paradissis, D., Veis, G., Cross, P.A., Denys, P.H., Ashkenazi, V., Bingley, R., Kahle, H.-G., Muller, M.-V., and Briole, P., 1998. Crustal strain in central Greece from repeated GPS measurements in the interval 1989-1997, Geophys. J. Int., 135(1), 195-214. 
De Martini, P.-M., Pantosti, D., Palyvos, N., Lemeille, F., McNeill, L., and Collier, R., 2004. Slip rates of the Aigion and Eliki faults from uplifted marine terraces, Corinth Gulf, Greece, C.R.Geoscience, 336/4-5, 325-334, doi:10.1016/j.crte.2003.12.006.

Doutsos, T., and Poulimenos, G., 1992. Geometry and kinematics of active faults and their seismotectonics significance in the western Corinth - Patras rift (Greece), Journal. Structural Geology, 14 (6), 689-699.

Ganas, A., 1997. Fault Segmentation and Seismic Hazard Assessment in the Gulf of Evia Rift, central Greece, Unpublished PhD thesis, University of Reading, 369pp.

Ganas, A, Pavlides, S, and Karastathis, V., 2005. DEM-based morphometry of range-front escarpments in Attica, central Greece, and its relation to fault slip rates, Geomorphology, $65,301-319$.

Ganas, A., Shanov, S., Drakatos, G., Dobrev, N., Sboras, S., Tsimi, C., Frangov, G., and Pavlides, S., 2005. Active fault segmentation in southwest Bulgaria and Coulomb stress triggering of the 1904 earthquake sequence, Journal of Geodynamics, 40(2-3), 316-333.

Houghton, S., Roberts, G., Papanikolaou, I., McArthur, J. and Gilmour, M., 2003. New ${ }^{234} \mathrm{U}_{-}{ }^{230} \mathrm{Th}$ coral dates from the western Gulf of Corinth: Implications for extensional tectonics, Geophysical Research Letters, 30(19), art. no. 2013.

Jackson, J.A., Gagnepain, J., Houseman, G., King, G.C.P., Papadimitriou, P., Soufleris, C., and Virieux, J. 1982. Seismicity, normal faulting, and the geomorphological development of the Gulf of Corinth (Greece): the Corinth earthquakes of February and March 1981, Earth planet Sci. Lett., 141, 377-397.

Jackson, J.A., and Leeder, M., 1994. Drainage systems and the evolution of normal faults: an example from Pleasant Valley, Nevada. Journal of Structural Geology, 16, 1041-1059.

Keller, E., and Printer, N., 1996. Active Tectonics: Earthquakes, Uplift and Landscape, Prentice Hall, New Jersey.

Pavlides, S.B., Koukouvelas, I.K., Kokkalas, S., Stamatopoulos, L., Keramydas, D., and Tsodoulos, I., 2004. Late Holocene evolution of the East Eliki fault, Gulf of Corinth (Central Greece), Quaternary International, 115-116, 139-154.

Pantosti, D., De Martini, P.M., Koukouvelas, I., Stamatopoulos, L., Palyvos, N., Pucci, S., Lemeille, F., and Pavlides, S., 2004. Palaeoseismological investigations of the Aigion Fault (Gulf of Corinth,Greece), Comptes Rendus - Geoscience, 336, 335-342.

Roberts, G. P., and Koukouvelas, I., 1996. Structural and seismological segmentation of the Gulf of Corinth Fault System: implications for models of fault growth, Annali di Geofisica, XXXIX, 619-646.

Schmidt, J., 1879. Studien über Erdbeben, Carl Schottze, Leipzig, 68-83pp.

Stein, R., King, G.C.P., and Rundle, J., 1988. The growth of geological structures by repeated earthquakes: 2 Field examples of continental dip-slip faults, Journal of Geophysical Research, 93(B11),13319-13331.

Verrios, S., Zygouri, V., and Kokkalas, S., 2004. Morhotectonic analysis in the Eliki fault zone (Gulf of Corith, Greece). Bulletin of the Geological Society of Greece, Proceedings of the 10th International Congress, Thessaloniki, April 2004, vol. XXXVI, 1706-1715. 